\title{
Transcendentalist Catalogue Rhetoric: Vision Versus Form
}

\section{Citation}

Buell, Lawrence. 1968. Transcendentalist catalogue rhetoric: Vision versus form. American Literature 40(3): 325-339.

\section{Published Version}

http://dx.doi.org/10.2307/2923769

\section{Permanent link}

http://nrs.harvard.edu/urn-3:HUL.InstRepos:3355779

\section{Terms of Use}

This article was downloaded from Harvard University's DASH repository, and is made available under the terms and conditions applicable to Other Posted Material, as set forth at http:// nrs.harvard.edu/urn-3:HUL.InstRepos:dash.current.terms-of-use\#LAA

\section{Share Your Story}

The Harvard community has made this article openly available.

Please share how this access benefits you. Submit a story.

\section{Accessibility}




\title{
Transcendentalist Catalogue Rhetoric: Vision Versus Form
}

\author{
LAWRENCE BUELL \\ Oberlin College
}

W 7 Hitman's catalogues are a most salient feature of his poetry, and certainly the most neglected. It is tempting to skip over them as we read. "The pure contralto sings in the organ loft," etc.-why bother with the rest? After all, we can predict what the next sixty lines will say. And so we pass quickly by the redundant images to follow the "movement" of the poem, whatever that is, so as to be able to come up with a theory of structure which will satisfy our struggling students, and our own rage for order. Dawdling among the catalogues only slows us down.

Still, when we allow ourselves to "loafe" awhile, we may be struck by Whitman's art in such passages, which at first seem the very antithesis of art. Sensitive discussions of Whitman, like Randall Jarrell's, show that other readers have felt the same way ${ }^{1}$ and the impact of catalogue rhetoric upon poets is certainly attested to by the tradition in American poetry which, following Whitman, employs it, not to mention the long antecedent tradition of prophetic

${ }^{1}$ See Jarrell's essay, "Some Lines from Whitman," in Poetry and the Age (New York, 1955), pp. Ior-120. Several more scholarly though less sensitive studies of Whitman's catalogues have been made. Mattie Swayne, "Whitman's Catalogue Rhetoric," University of Texas Studies in English, XXI, I62-I78 (July, 1941), is illuminating on the underlying purpose of the catalogue but confines its discussion of the style itself mainly to the characteristic grammatical patterns used by Whitman. Detlev W. Schumann, "Enumerative Style and Its Significance in Whitman, Rilke, Werfel," Modern Language Quarterly, III, 171-204 (June, 1942), is chiefly valuable for general comparisons and contrasts among the three writers. Stanley K. Coffman, Jr., " 'Crossing Brookiyn Ferry': A Note on the Catalogue Technique in Whitman's Poetry," Modern Philology, LI, 225-232 (May, 1954), defends the artfulness of the catalogue as a structural device in terms of a particular example, as I attempt to do in the first section of this paper. Especially stimulating is Coffman's discussion of the progression of tone and idea within and between the two principal catalogues in "Brooklyn Ferry." Harry R. Warfel, "Whitman's Structural Principles in 'Spontaneous Me," College English, XVIII, 190-195 (Jan., 1957), detects unity and movement in the apparent randomness of another catalogue. All four scholars relate Whitman's use of the catalogue to transcendentalist idealism, and their observations-though quite brief, except in Miss Swayne's case-should be compared with mine below, as should Roger Asselineau's interpretation of catalogues as "spiritual exercises" in The Evolution of Walt Whitman: The Creation of a Book (Cambridge, Mass., 1962), pp. 102-103. 
poetry from the Bible to Blake. But not only can Whitman's catalogues be regarded as prominent examples of a pedigreed technique; in his case the device has special significance because it is the exact stylistic counterpart of an important article of transcedentalist philosophy, as advanced by himself, Thoreau, and especially Emerson, whose essays make use of the catalogue almost as frequently as Whitman's verse, and for similar reasons. In reading Emerson, indeed, we are apt to experience just the same sort of alternation of impatience and fascination as our mental mood switches from analysis to receptivity and back again. Such responses to Emerson may be less keen than to Whitman, because Emerson is writing in prose and his appeal is intellectual rather than sensuous; but by the same token, he writes oftener and more articulately about the aesthetic theory behind the catalogue, and it is to him we must frequently turn in order to understand Whitman's use of the technique.

In this essay, then, I shall want to consider the catalogue, in Whitman's verse and Emerson's essays, both as an aesthetic device and as the expression of transcendentalist thought, relying on Whitman for most of the examples and Emerson for most of the theory. In particular, I hope to defend the catalogue against the charge of formlessness which has frequently been made against it.

\section{I}

To see how a good Whitman catalogue works, let us examine the following lyric from "Calamus":

Roots and leaves themselves alone are these,

Scents brought to $\mathrm{me}[\mathrm{n}]$ and women from the wild woods and pond-side, ${ }^{3}$

Breast-sorrel and pinks of love, fingers that wind around tighter than vines,

Gushes from the throats of birds hid in the foliage of trees as the sun is risen,

Breezes of land and love sent from living shores to you on the living sea, to you $O$ sailors!

The following and all subsequent quotations from Whitman are from Leaves of Grass, Comprehensive Reader's Edition, ed. Harold W. Blodgett and Sculley Bradley (New York, 1967).

"I cannot believe that "me" in this line is correct. It makes no sense, and it is not to be found in any previous printings of the 1892 or 1860 editions which I have consulted. 
Frost-mellow'd berries and Third-month twigs offer'd fresh to young persons wandering out in the fields when the winter breaks up,

Love-buds put before you and within you whoever you are, Buds to be unfolded on the old terms,

If you bring the warmth of the sun to them they will open and bring form, color, perfume, to you,

If you become the aliment and the wet they will become flowers, fruits, tall branches and trees.

Upon first reading, the poem appears to be little more than it says it is: a cluster of images, placed in loose apposition, with a bit of moralizing at the end. The casual bouquet is presented to the reader as if unsorted and not yet even in bloom. "Roots and leaves themselves alone are these"-these lines, in other words, which are to the finished poem what buds are to flowers. These buds of language are "to be unfolded on the old terms": we must "bring the warmth of the sun to them" and supply the nourishment ourselves if the cluster is to blossom for us. In plain language, Whitman seems to be saying that his poem, more than most, depends for its meaningfulness upon our participation. This is true, and not merely of this one lyric, but of all of Whitman's poetry. It requires us to take part in two main ways.

First, the reader must respond sensuously: smell the scents; feel the fingers tighter than vines, and the breezes; hear the gushes from the throats of birds; taste the frost-mellowed berries; and behold all. This is not as easy to do as it may seem. The sensuous appeal of poetry is made via the intellect and is too often weakened in the process; it is one thing to recognize the technique of synesthesia used here, another thing to participate in it. The odors in the poem, for instance, are much more apt to come across as "perfume" in the abstract than as the particular scents of "breast-sorrel and pinks of love." After all, most readers do not know what sorrel and pinks smell like, and the mixture of floral and human odors here implied may seem droll or repulsive (though only to the mind, not to the lover actually experiencing the sensation), so that the degree to which even the most sensitive reader can unfold such buds as these is bound to be limited. Nevertheless, a greater opening of the senses than is 
usually made in reading poetry is possible here, and if we can so respond, the buds will open and bring color and perfume to us. And in the same manner, all of Whitman's good catalogues will be felt as far richer than most poems.

But, one might argue, not only must the buds blossom; they must also be arranged, in order to be fully satisfying as art. As will soon become evident, I think this proposition is debatable, but since Whitman does promise that his buds can take "form" for us, we may assume that a second demand a Whitman catalogue makes upon us is the perception of some sort of design. So, too, does most poetry; but in Whitman's case, the demand is more difficult, because it is made so faintly. To find structure in Whitman's catalogues, beyond the obvious and rudimentary prosodic controls, is much harder than responding to them sensuously. In the "Calamus" poem quoted above, one immediately feels that some of the images could be repositioned with almost equal effect; that in places words, phrases, and even lines could be excised or added without doing great violence to the poem. Still, like a surprising number of Whitman's catalogues and catalogue poems, it has a definite organization, as subtle in its own way as a good lyric by that modern master of plethora, Dylan Thomas.

To begin with, the very miscellaneousness of the poem is a kind of unity. "A great disorder is an order," as Stevens's Connoisseur of Chaos says. Roots, leaves, scents, vine-like fingers, breast-sorrel, pinks, and all the rest come tumbling out of Whitman's horn of plenty, creating the impression of all nature (here a metaphor for the poet's words) burgeoning to unfold itself to the lover-reader. Through the piling up of images in every line Whitman conveys the sense of plentitude which is also his message.

Indeed throughout Whitman a main purpose of the catalogue seems to be to express the boundless fecundity of nature and human life, and thereby his own "leaves" also. The tone varies, of course. In "Roots and Leaves" it is loving and intimate. Elsewhere the poet may be filled with a religious awe, as in "limitless are leaves stiff or drooping in the fields. ..." And sometimes the catalogue has a comic aspect: 
I find I incorporate gneiss, coal, long-threaded moss, fruits, grains, esculent roots,

And am stucco'd with quadrupeds and birds all over ....

("Song of Myself," 11. 670-671)

These lines are of special interest, because they show in miniature how, in the midst of apparent randomness, Whitman may structure his lists in a second and more subtle way, so as to express something more than mere plenitude. At first, we probably feel a kind of bemused amazement: gneiss, coal, long-threaded moss, fruits, grains, esculent roots-how in the world did all these diverse things get thrown together in one package? The speaker seems just as surprised as the reader: "I find I incorporate" so many different things, he exclaims. The heterogeneity of the list is positively droll, especially the zoological collage in the second line. But despite this initial response, and the fact that it depends partly upon the sense that the items in the passage are as unrelated as the items in a garbage can, we can find a careful and significant arrangement of parts. Word sounds help to paste them together, subliminally, as it were. Gneiss-moss, fruits-roots, stucco-quadrupeds-these are some examples of coherence by means of alliteration and assonance. But in addition to this, Whitman has listed the items in an almostevolutionary order, beginning with gneiss, which is inanimate, and moving up the scale of being to quadrupeds and birds. The lines which follow give the key to the progression:

And have distanced what is behind me for good reasons,

But call any thing back again when I desire it. (11. 672-673)

The " $\mathrm{I}$ " of the passage, that is, personifies the evolutionary process, which has just unscrolled itself in the previous catalogue.

In "Roots and Leaves" as well, the sheer proliferation of images is like an ornate screen which hides as much of Whitman's artistry as it exhibits. Other devices lie behind it, implicit. One, already noted, is the appeal to all five senses. Parallelism, too, shapes and gives emphasis: in lines $7-8$, which point to the moral, and 9-10, which draw the conclusion, for example. More subtle is the alternation earlier in the poem of lines which merely list $(1,3,4)$ with lines that connect the images to a subject $(2,5,6)$ and are constructed around the pattern noun-past-participle-to-subject-(from- 
place). One wonders if this pattern was consciously formulated, but its existence shows, in any case, a sense of order on Whitman's part. There is even a visual pattern in the lines, a little like the floral arrangement of Thoreau's "Sic Vita." The first six lines are progressively longer; then two short lines make the assertion which ties together what precedes, while the implications dangle like the stems in a bouquet in the two longer lines at the end of the poem.

In order to show that Whitman's catalogues can be as rich in unity as they are in diversity, I have deliberately chosen good examples. Often, it is true, the structure of his catalogues consists almost wholly in their plenitude, in the parallelism of piled-up, endstopped lines, producing, at its worst, rudimentary paeans or chants like litanies from the Book of Common Prayer. But often enough both tone and structure are more complex, creating tapestries of imagery and rhetoric which are fine by any standard, like the eighth section of "Song of Myself," section three of "Brooklyn Ferry," and the two shorter examples analyzed here. We tend not to acknowledge the art of such passages, partly because we read Whitman's good catalogues with his bad ones in mind, but partly because Whitman's art is so implicit. His verbal pyrotechnics are meant to seem spontaneous, but that does not mean they are.

And yet because Whitman's art is so implicit it is dangerous to analyze it too persistently in the way I have just done, stressing the instances of sophisticated design in his catalogues. It is necessary to realize that such design can be found, but wrong to attach too much significance to it. In so doing we are liable to rest in a too simple evaluation of Whitman's poetry: to divide his catalogues into a small group which have design and are therefore "good," and a large group which are relatively amorphous and therefore "flawed." Such a polarization ignores the fact that the element of structure in a Whitman catalogue-indeed in any Whitman poem-even where refined, is relatively unstressed. The order of importance is the order in which we have proceeded: the individual sensuous and emotional responses are paramount, then the sense of plenitude, and lastly, when it exists, the design. Nor is this order of priority mainly the result of sloppiness or incapacity on Whitman's part, though these doubtless contributed. Rather it reflects Whitman's conscious aesthetic purpose, which will become more clear as we define, in 
the next section, the sense of values which underlies the catalogue technique.

II

It has been noted that among his contemporaries Whitman was by no means the sole maker of literary catalogues. Emerson, Thoreau, and even Melville also used the device; indeed, the paratactic and reiterative qualities of Emerson's and Thoreau's prose are so strong that in places they are indistinguishable from Whitman's verse.

What was responsible for this affinity? Partly, no doubt, the stylistic influence of Emerson and/or Carlyle. But a more basic reason is that the catalogue expresses a particular way of looking at the world, one which has its roots in transcendentalist idealism but was shared with Emerson and Thoreau by Whitman and, to a lesser extent, Melville.

A look at a representative Emerson catalogue, from "Compensation," will help show the connection:

The world globes itself in a drop of dew. The microscope cannot find the animalcule which is less perfect for being little. Eyes, ears, taste, smell, motion, resistance, appetite, and organs of reproduction that take hold on eternity,-all find room to consist in the small creature. So do we put our life into every act. The true doctrine of omnipresence is that God reappears with all his parts in every moss and cobweb. The value of the universe contrives to throw itself into every point. If the good is there, so is the evil; if the affinity, so the repulsion; if the force, so the limitation. ${ }^{4}$

Stylistically, this paragraph differs from Whitman's catalogues only in the irregular length of its items and their predominantly intellectual appeal. In Whitmanian fashion, each sentence repeats the first assertion in a fresh context. The doctrine of the microcosm is justified in turn by microbiology, human action, theology, metaphysics, and the laws of morality and physics. Like the separate lines of Whitman's catalogues, Emerson's sentences give the appearance of being self-contained and interchangeable; transitions are at a minimum; and it seems as if sentences could be added or deleted

t The Complete Works of Ralph Waldo Emerson, ed. Edward Waldo Emerson (Boston, 1903-1904), II, IOI-102. 
without cost. But again like Whitman, closer inspection shows that rhythm and Emerson's tactic of moving from the elementary (dewdrop, animalcule) to the more significant (human action, doctrine of omnipresence) do give the order of the paragraph a certain amount of inevitability. And again, this twofold impression the passage makes is well suited to what seems to be Emerson's purpose-to overwhelm us with the multiplicity of instances but at the same time impress us with the design inherent in these. The sentences are the dewdrops, and the paragraph is the world.

But more noteworthy than the parallels between Emerson's lists and Whitman's is the fact that this paragraph reveals the basis for those affinities, the principle of microcosm itself. In both writers, this principle underlies and, to a great extent, determines the use of the catalogue. Elsewhere Emerson's criticism makes this quite plain. Because every particular nature is a symbol of spirit, all natures, he argues, are related to each other by analogy: "each creature is only a modification of the other" $(I, 44)$. And just as symbol and analogy are the bases of natural law, so they are the chief methods of literary style, for a work of art is properly "an abstract or epitome of the world .... the result or expression of nature, in miniature" $(\mathrm{I}, 23)$. In the process of composition (another term which Emerson characteristically uses with double reference to rhetoric and nature, to denote the arrangement of parts both in a landscape and in a discourse), analogy is of special importance. For the order of nature is a unity of endless variety, in a constant state of flux, with all objects blending together on the one hand, and melting into spirit on the other - "as the bird alights on the bough, then plunges into the air again, so the thoughts of God pause but for a moment in any form" (VIII, 15). Therefore "the quality of the imagination" must likewise be "to flow, and not to freeze" (III, 34). The "essential mark" of good poetry "is that it betrays in every word instant activity of mind, shown in new uses of every fact and image, in preternatural quickness or perception of relations" (VIII, I7).

The foregoing analysis gives Emerson's essential view of the subject, but there is, we should note, one important inconsistency, due to Emerson's ambivalent and changing philosophy of nature. In Nature a rigid conception of nature as a closed system of $\mathrm{r}: \mathrm{I}$ correspondences is adumbrated in "Language," side by side with the more flexible view just analyzed, which is expressed in "Discipline" and "Idealism." The former notion, 
The rapidity of metamorphosis which Emerson perceives in nature and demands of literature is precisely the outstanding feature of his own dazzling batteries of aphorisms in such passages as the one from "Compensation" quoted above. For many readers, this quality has seemed the hallmark of his style and thought, as distinctive to him as the verse catalogue is to Whitman. "The whole fascination of life" for Emerson, O. W. Firkins once wrote, without much exaggeration, "lay in the disclosure of identity in variety, that is in the concurrence, the running together, of several distinct images or ideas."

A similar sense of nature's unity in diversity, we have seen, underlies the plenitude of images in the Whitman catalogues discussed earlier. But Whitman, less concerned with man's relation to nature than with his relation to other men, characteristically expressed the principle in a way slightly different from Emerson. He accentuated its democratic side, so to speak. Whitman's fundamental purpose in Leaves of Grass, as he often said, was "to articulate and faithfully express in literary or poetic form, and uncompromisingly, my own physical, emotional, moral, intellectual, and aesthetic Personality, in the midst of, and tallying, the momentous spirit and facts of its immediate days, and of current America." This plan, however, had much the same implications for style as Emerson's theory of nature, because Whitman shared Emerson's basic assumption of divine immanence. For this reason, the persona-the " $\mathrm{I}$ "- in Whitman's poetry is, like the "self" described in "Self-Reliance," not merely individual but cosmic, and as such can participate in the experiences of all men in the same way that Emerson's Oversoul inheres in all men and all parts of nature. For rendering this collective conception of the self poetically, the catalogue is a most appro-

derived mainly from Swedenborg and his disciples, Emerson never quite outgrew; it comforted him, perhaps, to go on believing that natural objects "are really parts of a symmetrical universe, like words of a sentence; and if their true order is found, the poet can read their divine significance orderly as in a Bible" (VIII, 8). But for the most part, the idea of a symbolic universe was a liberating, rather than a restricting conception for Emerson, and he liked to stress the versatility of the symbol both in nature and in the poet's hands. In "The Poet" he specifically repudiated the point of view of the "mystic," who "nails a symbol to one sense, which was a true sense for a moment, but soon becomes old and false" (III, 34).

"Ralph Waldo Emerson (Cambridge, Mass., 1915), p. 237.

'A Backward Glance o'er Travel'd Roads," p. 563. 
priate technique. Through it, the self can be sung in such a way as to incorporate, or seem to incorporate, all particular selves. "Of these one and all I weave the song of myself," Whitman says at the end of one long catalogue. "These" are the disparate images of human life which the poet has just listed, to the end of showing how, "one and all," they are united in "myself." The method of the song mirrors the complex unity of the singer.

We must be careful, of course, not to apply the principle of unity in diversity to the analysis of catalogue rhetoric in a too mechanical way, to reduce every catalogue to an illustration of the principle. Nobody writes great poetry on principle, at least not very often. On the contrary, it is likely that the flatness of Whitman's later poetry, for example, was caused at least in part by writing from principle, by imitating himself, as it were. And yet the connection between paratactic style and microcosmic universe was undeniably felt by him and by Emerson; it was not merely a matter of principle but of perception. Thoreau's sensitivity to it was equally keen (see the conclusion to his description of the thawing Walden hillside in "Spring") and so, almost, was Melville's. Melville is an especially interesting case because he was writing out of doubt instead of affirmation and yet adapted the catalogue brilliantly to those ends in the rhetoric of such passages as "The Whiteness of the Whale." Unlike the other three writers, he exploited the ironic possibilities of the technique: the variety of instances Ishmael cites may or may not have unity; the appearances may or may not be significant. But the habit of conveying ideas by means of a barrage of linked analogies is distinctively transcendental. It is the end product of transcendentalism's cardinal tenet: that the Oversoul is immanent in all persons and things, which are all thereby symbols of spirit and conjoined by analogy in an organic universe.

\section{III}

The fact that the transcendental catalogue is based upon the sense of the universe's spiritual unity in diversity makes it unique in Western literature. Though the catalogue as a literary device is as old as Homer, and the principle of plenitude is almost as hoary, in no other period, so far as I know, are the technique and the 
Weltanschauung fused so closely as they are in the American renaissance.

This fusion, to my mind, accounts for a good deal of the richness and fascination of transcendentalist literature. It has not, however, tended to arouse much enthusiasm in other readers. An important reason for this seems to be that it also goes far in explaining why, in the style of the catalogue, structure plays a subordinate role and why, in general, transcendentalist literature is often rather formless. For Emerson, Whitman, and Thoreau all regarded art pragmatically, that is, as properly the expression of something beyond itself-call it vision, truth, or what you will; they were, in short, not trying to write poems but nature; and they were therefore convinced that the secret of design in art rested rather in the ability to perceive the natural order than in imposing an aesthetic order upon their perceptions. Thus Thoreau structured his major works around the days of the week or the course of the seasons or the sequence of a journey; Whitman, for his controlling motifs in "Lilacs" to "Passage to India," relied on personal experience and contemporary history; and Emerson arranged his first book and many subsequent essays in what he considered were natural orders, hierarchical and dialectical patterns chiefly. Clearly all three believed that there was design in nature and likewise valued design in art; but they did not believe in making the latter an end in itself. And so we find Emerson exclaiming in one place: "It is much to write sentences; it is more to add method, and write out the spirit of your life symmetrically ... to arrange many general reflections in their natural order so that I shall have one homogeneous piece"-but affirming elsewhere that "the truthspeaker may dismiss all solicitude as to the proportion and congruency of the aggregate of his thoughts, so long as he is a faithful reporter of particular impressions."

Recent criticism, setting a high valuation upon structure, has often been nettled by this second attitude and blamed transcendentalist art for insufficient attention to form and transcendentalist criticism for making art the handmaiden of its nebulous doctrines. Such criticisms invariably hold up the catalogue as the epitome of these deficiencies. Charles Feidelson, for example, has argued in the case

' Journals of Ralph Waldo Emerson, ed. Edward Waldo Emerson (Boston, 1909-1914), VI, $47-48$, and $V, 327$. 
of Emerson that the principle of unity in diversity inhibits him as a symbolist because when applied as a concept of structure it provides "no brake on the transmutation of form" and thus easily degenerates into a mere multiplication of instances. ${ }^{\circ}$

$\mathrm{Up}_{\mathrm{p}}$ to a point, this line of reasoning is persuasive. Plenitude, both as a theory of nature and as a theory of structure is, in itself, a quite elementary conception. In fact, from remarks like Emerson's last, one suspects that the transcendentalists used it partly just as a substitute for something better: that they seized upon it as a formula for order partly because it was such a convenient way of accounting for the prevailing disorder. The principle was specific enough to give them a sense of design, yet vague enough to relieve them of the need to order their thoughts more rigorously-a difficult problem to begin with for diarists like Emerson and Thoreau or an imagist like Whitman. As a result, their catalogues, like the thought which produced them, seem fitted as structures for the short run only. In the more elementary units of composition-the short lyric, the paragraph, the passage: in other words, the kinds of examples analyzed above-they were able to do impressive things with plenitude as an ordering principle, but when they extended themselves further they lapsed into sheer itemization. Perhaps Whitman had this problem in mind when he made the decision to divide his longer poems into sections or when, in his old age, he stated his agreement with Poe's dictum that there is no such thing as a long poem. ${ }^{10}$

But is "Roots and Leaves" really a better poem than "Song of Myself," or even a better catalogue than the longest section of the "Song," section 33, which is much less tightly knit than many of Whitman's shorter lists? State the issue this way and at once we sense that it is risky to disparage the catalogue for formlessness, even where it is clearly amorphous, and riskier still to chastise the transcendentalist world view, however simple, for cramping its style.

- Symbolism and American Literature (Chicago, 1953), p. 150. See also René Wellek's section on Emerson in A History of Modern Criticism (New Haven, Conn., 1965), III, 163176. "For both scholars, the catalogue and the principle of plenitude behind it seem to represent what is weakest in Emerson's art and criticism." Both discussions, especially Feidelson's, are very provocative, and it will be obvious to the reader that I have been influenced by them even while reacting against them.

10 "A Backward Glance," op. cit., p. 569. 
Where the lines are good, who cares about the structure? Where the philosophy makes good poetry, why cut off the stream at its source?

The passage just referred to begins with a beautiful eighty-line list of places visited by the singer, now "afoot with my vision" more ecstatically than at any other place in the poem. The voyager sees, for example:

Where herds of buffalo make a crawling spread of the square miles far and near,

Where the humming-bird shimmers, where the neck of the long-lived swan is curving, and winding,

Where the laughing-gull scoots by the shore, where she laughs her near-human laugh,

Where bee-hives range on a gray bench in the garden half hid by the high weeds,

Where band-neck'd partridges roost in a ring on the ground with their heads out .... (11. $761-765)$

The list could be, and is meant to seem, endless. It is the longest and loosest catalogue in a long, loose poem. Even in these five lines, the connection among the images is tenuous. All are pictures of wildlife, and one could say something about interplay between motion and rest or near and distant perspective, but the true impact of these lines does not really depend upon such relations, any more than it depends elsewhere in Whitman upon almost-evolutionary orders or the tailoring of a poem's shape to look like a bouquet of flowers. The contribution of rhythm excepted, it consists in the language ("crawling spread of the square miles," "humming-bird shimmers," "scoots by the shore," "range on a gray bench in the garden half hid," "roost in a ring on the ground with their heads out," etc.) and the tremendous sense of vitality conveyed by running these and many more epiphanies together-a vitality made more intense by those phrases within individual lines whose sounds slide and bounce into one another, as in the five phrases just quoted. Texture and vision: these, in short, are what make the passage beautiful. We cannot share as doctrine the Emersonian idea that every creature is only a modification of every other, but we can experience it by allowing ourselves to drift with the speaker through these images. 
Indeed we have to experience it, even accept it, if we are to read the passage, since the visionary element is inextricable from the best "poetic" qualities of these and other Whitman catalogues. In its ascendency, this element forces structure and aesthetic considerations generally to play second fiddle, but at the same time produces great poetry. Our recognition of this fact needs to be less grudging. We tend to separate inspiration from craftsmanship as naively as the transcendentalists confused them, and so are deprived of the critical habits and terminology needed to appreciate works which are committed to the use of style as a vehicle for vision. The distinction, to be sure, is important, but when taken as inherent rather than provisional it prevents us from reading a catalogue for anything more than the pictures. The poet and the prophet are not so easily divorced; and we may even find that it is the second which makes the first worthwhile, if we will permit ourselves to think like Old Critics for a moment. In much good literature, I should venture to say, and certainly in literature so vatic as the transcendentalists', the literary expression is only the beginning, albeit an indispensable beginning, of its appeal, just as it was only the result or end product of the forces which produced it.

Such, at any rate, was the opinion of the transcendentalists. The basic message they had to offer, if one may generalize so sweepingly about a field so wide and hazy, was power. Books, as Emerson wrote in "The American Scholar," "are for nothing but to inspire" (I, 89). This purpose finds impetus and justification in the principle of plenitude, the idea of microcosm underlying it, and the belief in divine immanence which is at the heart of both. All of these are essentially doctrines of open-endedness, promising limitless possibilities for adumbration, refinement, and growth. To the end of expressing these conceptions, and above all the sense of power from which they spring, the catalogue is ideally suited. Even where formless-indeed, we could say, especially where formless-the catalogue has the potential for power. Its very rawness makes it all the more vigorous and striking.

The structural limitations of the catalogue, then, are finally irrelevant. It is meant to be wild; the inspired poet, as Emerson put it, "knows that he speaks adequately ... only when he speaks somewhat wildly" (III, 27). If there is a limit to the length a 
catalogue can be sustained, it is not so much in the number as the quality of the items. We could easily dispense with a "Salut au Monde," but that does not mean that another catalogue poem of the same length cannot succeed. Naturally, just as the mixture of short and long sentences in a paragraph makes for a pleasing variety, so in a poem of sizable proportions or a prose work as long as an Emerson essay, discursive passages are most effective if punctuated by terse ones. The same rule of variety applies in miniature to rhythm and line-length, as Emerson's less inspired efforts in iambic tetrameter couplets attest. But both expansion and concentration can be equally effective; and so long as there are freshness and variety in the images, and a minimum amount of modulation from one item to the next in addition to mere juxtaposing, the catalogue can be prolonged almost indefinitely.

What the reader most needs to bring to the catalogue, perhaps, is a sense of abandonment. This does not mean the complete denial of the critical faculty, but only its suspension, for as long as it takes to get caught up, or at least to give the piece a fair trial. One feels that whatever intricate design a catalogue may later be seen to have, it is essentially an outpouring, intended to stir up, not to settle. Maybe this is partly why Whitman, in so many poems like "Roots and Leaves," explicitly beckons to the reader and invites him to participate. An Emerson paragraph makes the same demand, in its own way. It is not merely a bag of duckshot, as Carlyle suggested, speaking like a structural critic ${ }^{1}$ it is a bag of snakes. And the fact that so often critics, even as they deplore the lack of discipline in Emerson's prose, line their own paragraphs with his aphorisms, shows that they are still hissing.

${ }^{11}$ The Correspondence of Emerson and Carlyle, ed. Joseph Slater (New York and London, 1964), p. 37 I. 